\title{
The Early Devonian eurypterid Grossopterus overathi (Gross, 1933) from Overath, Germany
}

\author{
Jason A. Dunlop ${ }^{1}$, Simon J. Braddy ${ }^{2}$ \& Erik Tetlie $^{2}$
}

With 6 figures

\begin{abstract}
The holotype and only known specimen of the eurypterid (Chelicerata: Eurypterida) Grossopterus overathi (Gross, 1933) from the Early Devonian (Siegennian) of Overath, north-west Germany is redescribed. Based on comparisons with other eurypterid taxa we interpret $G$. overathi as having a well-preserved type B genital appendage, which exhibits two apomorphic character states: (1) a furca fused into a single, spatulate plate and (2) marginal serrations near the distal end of the appendage. Grossopterus is assigned to the family Hughmilleriidae, but its carapace resembles that of the larger Slimonia acuminata (Salter, 1856) (Slimoniidae). A provisional phylogenetic analysis resolves Grossopterus as the sister group of (Slimonia + Pterygotoidea). The large pterygotids, in particular, have been suggested as significant predators on early vertebrates and hypotheses about eurypterid-fish co-evolution are reviewed, in particular Romer's proposal that dermal armour in fish evolved in response to eurypterid predation.
\end{abstract}

Key words: Devonian, north-west Germany, Overath, Eurypterida, Grossopterus, Genital appendage, fish, co-evolution.

\section{Zusammenfassung}

Der Holotyp - das einzig bekannte Exemplar - des Eurypteriden (Chelicerata: Eurypterida) Grossopterus overathi (Gross, 1933) aus dem frühen Devon (Siegennian) von Overath im nordwestlichen Deutschland wird wieder beschrieben. Basierend auf Vergleichen mit anderen Eurypteriden-Taxa interpretieren wir $G$. overathi als Träger eines Typ B-Anhanges, wobei zwei apomorphe Merkmalszustände vorliegen: (1) die Furca ist zu einer einzigen, spatelförmigen Platte verschmolzen, und (2) der Seitenrand nahe des distalen Endes des Genitalanhanges ist gezähnt. Grossopterus wird zur Familie der Hughmilleriidae gestellt, aber der prosomale Dorsalschild ähnelt der größeren Slimonia acuminata (Salter, 1856) (Slimoniidae). Eine vorläufige phylogenetische Analyse zeigt Grossopterus als Schwesteruppe von (Slimonia + Pterygotoidea) auf. Besonders die großen Pterygotiden wurden als signifikante Prädatoren von frühen Vertebraten gehandelt, und Hypothesen zur Eurypteriden-Fisch Koevolution werden überprüft, speziell Romers Vorschlag, dass die dermale Panzerung von Fischen als Antwort auf die Prädation durch Eurypteriden evolvierte.

Schlüsselwörter: Devon, Nordwestdeutschland, Overath, Eurypterida, Grossopterus, Genitalanhang, Fische, Co-Evolution.

\section{Introduction}

In 1933 Walter Gross described a fauna of fish and eurypterids collected by himself and Walter Schriel from Early Devonian sediments at a quarry in Overath, near Cologne, Germany. Among the fossils figured by Gross (1933) were fragments of pterygotid eurypterids and an almost complete specimen which he named Eurypterus (?) overathi Gross, 1933. Subsequently, W. Gross invited Leif Størmer to re-examine this eurypterid material. Størmer (1934) redescribed $E$. (?) overathi in some detail and established a new genus for it, Grossopterus Størmer, 1934, which he named after Gross and diagnosed on characters such as the carapace shape with incurving lateral margins and the shape of the genital appendage (see also below). In the same paper an incomplete specimen from the Middle Devonian of the USA, Pterygotus inexpectans Ruedemann, 1921 was tentatively referred to this new genus. $G$. overathi was also figured in

\footnotetext{
${ }^{1}$ Museum für Naturkunde, Institut für Systematische Zoologie, Invalidenstraße 43, D-10115 Berlin, Germany. E-mail: jason.dunlop@museum.hu-berlin.de

2 Department of Earth Sciences, University of Bristol, Wills Memorial Building, Queens Road, Bristol, BS8 1RJ, UK.

E-mail: S.J.Braddy@bristol.ac.uk and O.E.Tetlie@bristol.ac.uk

Received February 2002, accepted May 2002
} 
the Treatise on Invertebrate Paleontology (Størmer 1955).

Work on eurypterid systematics was dominated in the mid- $20^{\text {th }}$ century by Leif Størmer, Erik Kjellesvig-Waering and Charles Waterston. However, since the late 1970s most publications on eurypterids have been palaeobiological, together with the descriptions of a few new taxa. With the exception of Tollerton's (1989) valuable compilation of genera and suprageneric taxa, there have been few recent systematic revisions. Tollerton (1989, table 8) recognised over sixty valid eurypterid genera (excluding the unusual cyrtoctenids), at least seven of which could not be placed within his familial scheme because they were based on incomplete, or even fragmentary, material. Indeed, eurypterid systematics is plagued by taxa raised on isolated head shields (Ruedemann 1921), telsons (KjellesvigWaering 1951, 1973) or the dentition of disarticulated chelicerae (Kjellesvig-Waering 1964), and on names assigned to non-descript stains and other non-eurypterid material; see e.g. Tollerton's (1994) comments on many of the Ordovician taxa from New York State.

Tollerton's (1989) typological scheme of higher systematics has not been translated into a parsimony-based model of eurypterid evolution. The only comprehensive cladistic analyses are in the unpublished theses of Plotnick (1983) and Braddy (1996); a version of Plotnick's cladogram was figured by Beall \& Labandeira (1990), but without accompanying discussion. There is also a published analysis of the pterygotid genera by Plotnick \& Baumiller (1988). Redescriptions of some of the less well known or taxonomically complex genera are an important prerequisite for scoring characters into future phylogenetic studies; see also comments in Braddy (2000).

In this paper we redecribe $G$. overathi as part of a wider systematic revision of the Eurypterida. In contrast to Størmer (1934), we reinterpret its genital appendage as a type B appendage, but one in which the distal furca has fused into a spatulate plate with marginal serrations. This diagnostic character appears to be autapomorphic for the genus. Grossopterus shares potential characters with members of the Hughmilleriidae, to which it was originally assigned (Størmer 1955, Tollerton 1989), but also with the larger Slimonia acuminata (Salter, 1856) (Slimoniidae). Here, we present a preliminary phylogenetic analysis based on selected taxa, the results of which imply that $G$. overathi, S. acuminata and the pterygotid eurypterids may form a clade. $G$. overathi could, therefore, be a basal member of the lineage which led to some of the largest eurypterids; arthropods up to two metres long which are popularly perceived as having been significant predators on early vertebrates. As at Overath, Siluro-Devonian eurypterids are often found in association with fish, leading Romer (1933) to speculate that eurypterids exerted a selective pressure for the development of vertebrate dermal armour. This hypothesis is discussed below in the light of recent critical remarks.

\section{Material}

Both Gross (1933) and Størmer (1934) cited the type repository of $G$. overathi as the Geologisches Landesmuseum Berlin. The Landesmuseum material now forms the palaeontological collection of the Museum für Naturkunde, Berlin (MfN) and the holotype, and only specimen, of G. overathi is held here in the arthropod palaeontology collections under the repository number MB.A. $2 a+b$ (i.e. part and counterpart). The holotype of $G$. overathi was examined under a stereomicroscope with a camera lucida attachment used to draw the genital region in detail. Specimens were compared to other eurypterid taxa, principally Baltoeurypterus Størmer, 1973, Erettopterus Salter, 1859, Slimonia Page, 1856 and Hughmilleria Sarle, 1903, based on the literature and material in various collections including the MfN, the Natural History Museum, London, the National Museum of Scotland, Edinburgh and the Sedgwick Museum, Cambridge. Terminology follows Størmer (1955) and Tollerton (1989) and also Selden (1981) for the appendages and Braddy \& Dunlop (1997) for the genitalia.

\section{Geological Setting}

Schriel (1933) described the stratigraphic and tectonic setting of the Overath fossils. The fish and eurypterids, including $G$. overathi, were collected from a $10-20 \mathrm{~cm}$ thick unit (Gross 1933) in the Heider quarry which belongs to the Wahnbach-Schichten of the Rheinische Schiefergebirge and was noted by Schriel as the most important locality for dating this Early Devonian formation in the Overath region. According to both Schriel (1933) and more recently Schweitzer (1983: table 4) the Wahnbach-Schichten is mid- to late Siegennian in age; a date also given on the $G$. overathi labels. The associated fish fauna from the Heider quarry includes agnathans, elasmobranchs and crossopterygians. A large amount of (mostly unidentified) plant material was also reported (see Gross 1933 for details). 

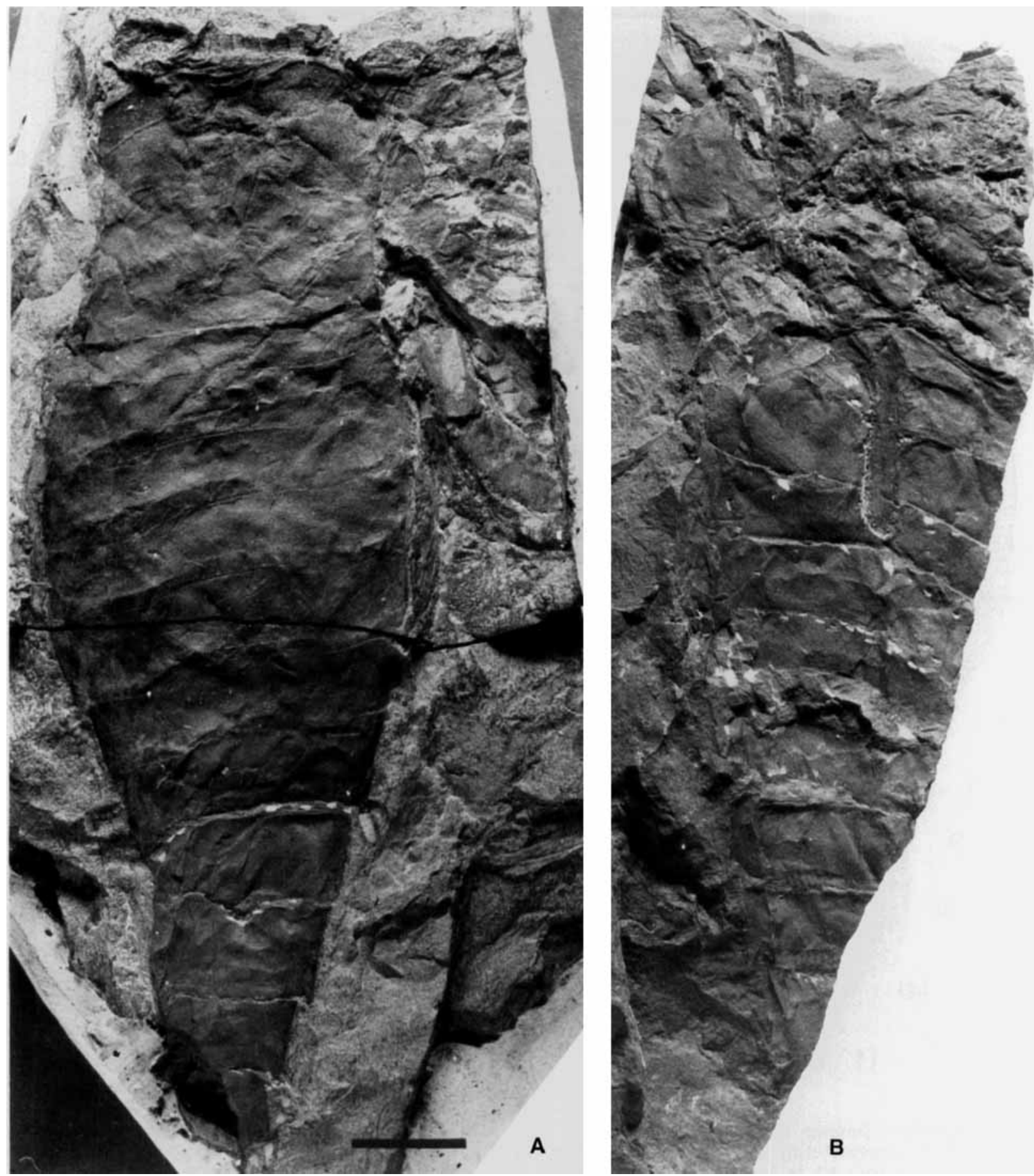

Fig. 1. Grossopterus overathi (Gross, 1933). MB.A. 2a + b. From the Early Devonian (Siegennian) Wahnbach-Schichten, collected at the Heider quarry near Overath, Nordrhein-Westfalen, Germany. A. Dorsal surface showing prosomal dorsal shield (or carapace), most of the opisthosoma and some appendages. B. Ventral surface showing the metastoma, some coxal elements and an incomplete opisthosoma with a prominent genital appendage. Scale bar equals $20 \mathrm{~mm}$.

\section{Morphological interpretation}

General: Grossopterus is preserved in a dark grey shale with relatively little visible lamination (Fig. 1). The matrix around the part, showing the dorsal surface, is coloured bluish-grey which contrasts against the dark brown specimen. This blue colouration is not seen on the counterpart.
The part has a split through the middle of the animal and both halves are mounted together in a plaster of Paris jacket. Grossopterus is a small to medium-sized eurypterid with a body length of about $20 \mathrm{~cm}$ excluding the (absent) telson. It appears slightly larger and more robust than the otherwise similar genus Hughmilleria; especially with respect to the prosomal appendages. Gros- 

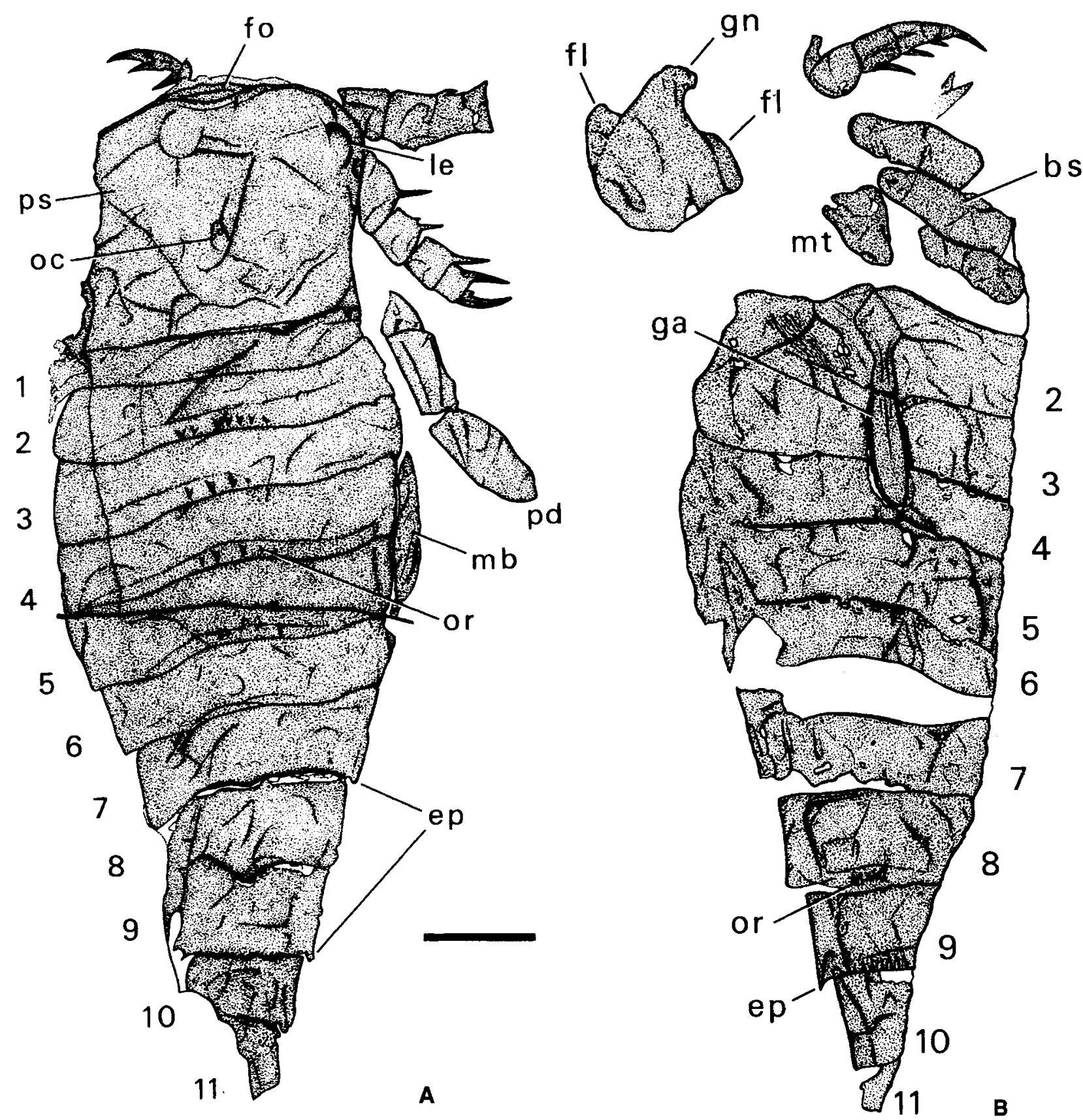

Fig. 2. Interpretative drawings of the specimens shown in Fig. 1. A. Dorsal view. B. Ventral view. Opisthosomal segments numbered (1-11) conventionally after Størmer (1955). Segment 12 not preserved. bs, basal appendage podomeres?; ep, epimera; fl, flanges on coxa VI; fo, folds near incurving anterior margin; ga, genital appendage; gn, gnathobase on coxa VI; le, reniform lateral eye tubercle; mb, possible membrane from between the dorsal and ventral surfaces; mt, metastoma; oc, probable site of ocelli or median eyes; or, ornament; pd, paddle (leg VI); ps, prosomal dorsal shield or carapace. Scale bar equals $20 \mathrm{~mm}$.

sopterus overathi is relatively complete (Figs 1, 2), the dorsal side more so than the ventral one, and the postabdomen has bent slightly to the left. The cuticle exhibits some folding and wrinkling; presumably taphonomic in origin. Under higher magnification the typical eurypterid cuticle ornament of lunules can be seen, especially on the ventral surface near the genital appendage (Fig. 3).
Prosoma: The prosomal dorsal shield, or carapace, is subrectangular, slightly wider than long and has a more or less straight posterior margin (Fig. 1A). As Størmer (1934) noted, the right margin of the carapace curves inwards; a similar morphology to that seen in the much larger Slimonia. The precise nature of this curvature was better expressed in Gross's drawings as compared to Størmer's and it is worth noting that 


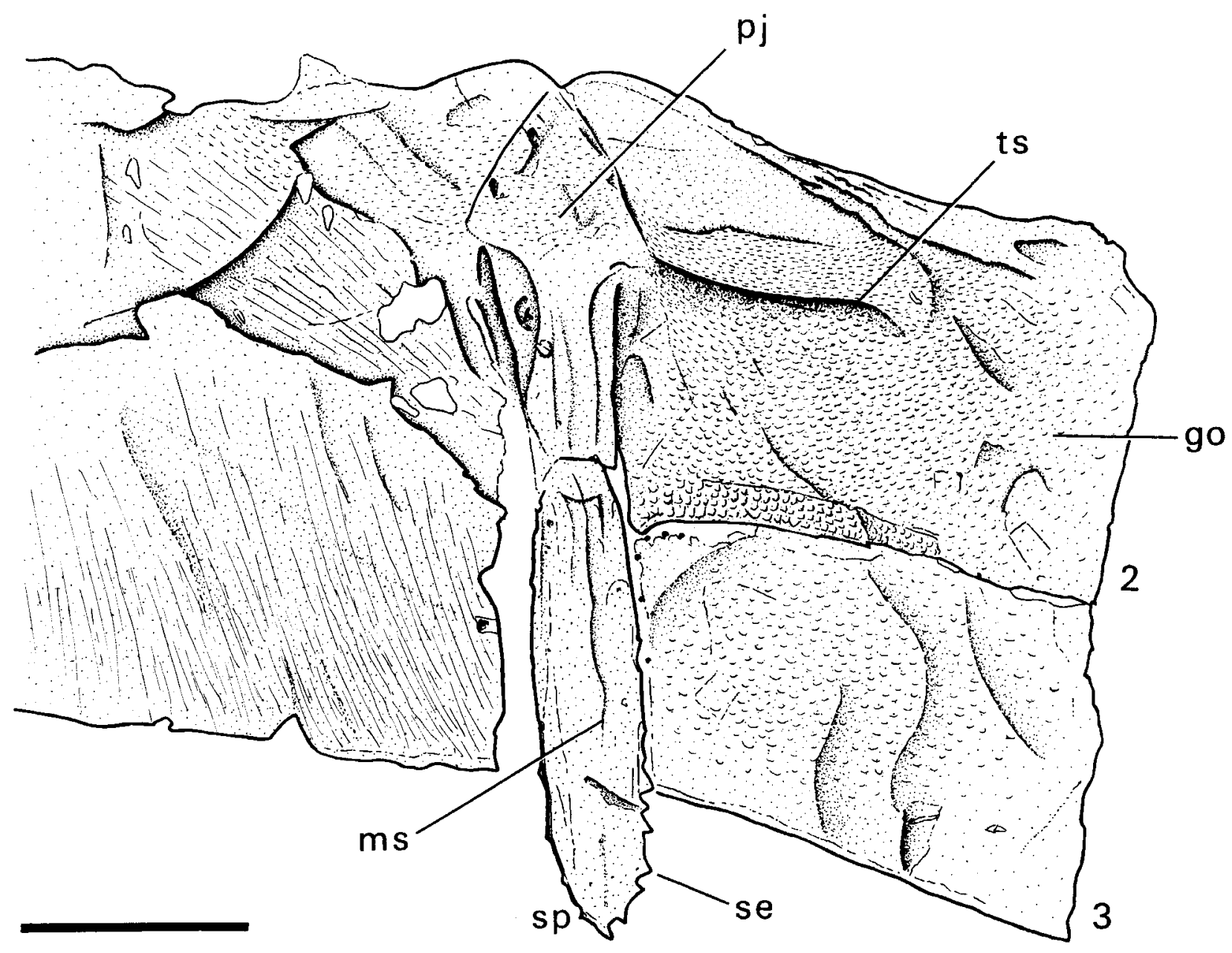

Fig. 3. Camera lucida drawing of the genital appendage in $G$. overathi and its associated operculum (2) plus the following operculum (3). go, genital operculum; ms, median suture line; pj, proximal joint of genital appendage, se, serration on appendage margin, sp, spatulate distal region of genital appendage, ts, transverse suture across genital operculum. Scale bar equals $10 \mathrm{~mm}$.

the whole animal has been inverted in the Treatise illustration (Størmer 1955: fig. 21(4a)). There is also a shallow incurving of the anterior margin in $G$. overathi close to the midline, associated with what appear to be a series of folds. The lateral eye tubercle is preserved only on the right side where it occupies an anterolateral position. It is reniform in shape and lies close to, but does not touch, the margin of the dorsal shield. The median eyes, or ocelli, are not clearly preserved, but a region on the midline, just into the posterior half of the dorsal shield (Fig. 2A), is consistent with being the median eye tubercle.

Four individual appendages can be seen in the part. The distal region of a small, spinose appendage (possibly appendage II) emerges from beneath the front of the dorsal shield. Two larger appendages (probably IV and V) are preserved on the right side. Both are robust and the posterior one is especially well preserved, lying on its lateral side to reveal five podomeres, including the terminal one formed into a curving spine. The other podomeres all have short, thick spines emerging from the distal, inferior margin and in the scheme of Tollerton (1989: fig. 8) this would match the Hughmilleria-type of spiniferous limb. The remaining appendage is clearly number VI, being modified into a swimming paddle. It is, however, rather small when compared to the paddles of similar taxa. At least three podomeres are visible, but it is difficult to resolve precise homologies for these limb elements and, in comparison to better preserved eurypterids, details of the structure of the paddle unit are obscure. In particular, podomere 7 a cannot be clearly seen and the entire paddle probably lies upside down, since it is preserved curving away from the body while in most eurypterids the paddle follows the curvature of the preabdomen.

On the counterpart the ventral prosomal region is poorly preserved (Figs 1B, 2B). On the left side it is possible to identify the enlarged 
coxa of limb VI. It has become displaced from its life position but the medial gnathobasic edge can still be identified (Fig. 2B: gn), albeit without the teeth of the gnathobase being preserved. This structure also has two distinct flanges: a mesal flange which in life would tuck under the metastoma (see below) and an anterior flange (cf. Parahughmilleria hefteri Størmer, 1973) of uncertain function. In front of the genital appendage is the metastoma. This plate-like structure (Fig. 2B) was not recognised by Størmer (1934) and is poorly preserved, but in outline it is bluntly rounded posteriorly and widens anteriorly forming a pair of curving shoulders giving it a more or less cardioid shape (cf. Tollerton 1989: figs 4-5). On the right side is an isolated limb, probably limb II or III judging by its position and small size compared to the large, spinous limb on the part. Superimposing the two camera lucida drawings suggests that this limb in the counterpart is not the small limb projecting from beneath the front of the carapace in the part. Posterior to this limb are three elements which could be part of the basal region of the legs, probably composed of two or more indistinctly preserved podomeres.

Opisthosoma: The opisthosoma of Grossopterus has a fairly smooth transition between the pre- and postabdomen. Twelve opisthosomal segments are traditionally recognised in eurypterids - seven in the preabdomen, five in the postabdomen - although there is some evidence for a vestigial segment between the carapace and the first visible tergite (see Dunlop \& Webster 1999 for a review). Since this segmentation question remains unresolved, the conventional scheme of numbering eurypterid segments sensu Størmer (1955) is adopted here. The posterior margins of tergites 2-5 have an ornament of raised, Vshaped scales. A region on the right side of the preabdomen appears to be slightly separated from the rest of the specimen with fold-like markings running more or less longitudinally. This may be the impression of the membrane between the tergites and sternites squeezed out laterally during compression, rather than part of the tergites themselves. The postabdominal segments show traces of small, lateral epimera on the posterior margin. Ventrally the posterior margins of segments 8 and 9 have an ornament of narrow, wedge-like structures. The pretelson (segment 12) and telson are not preserved. The structure of the genital appendage, and its associated operculum (Fig. 3), is considered below.

\section{Genital appendage}

Eurypterid genitalia are known in greatest detail from the Silurian genus Baltoeurypterus; see e.g. Wills (1965) and Braddy \& Dunlop (1997). Most well-preserved eurypterids exhibit sexual dimorphism (Figs 4-5) with so-called type A and type B genital appendages; although in taxa where ontogenetic series are preserved there can be variability even within one of these appendage morphologies (Waterston 1960, 1964). In Baltoeurypterus there is a fairly straightforward

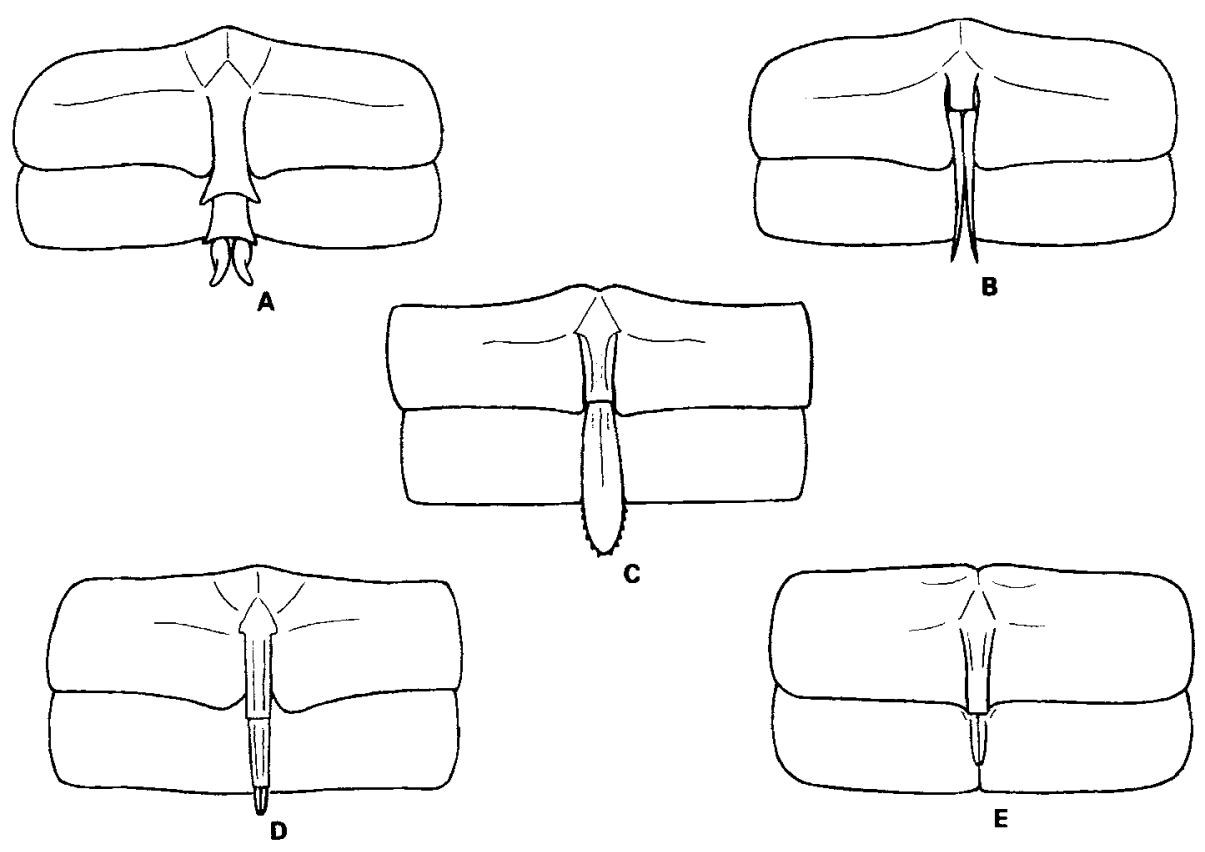

Fig. 4. Comparison of genital appendages in selected eurypterid taxa. A. Baltoeurypterus tetragonophthalmus - type A appendage. B. $B$. tetragonophthalmus - type B appendage. Both after Braddy \& Dunlop (1997: fig. 2). C. Grossopterus overathi (this study). D. Nanahughmilleria norvegica - type A appendage (?), after Størmer (1934: pl. 1). E. H. socialis - type B appendage (?), after Clarke \& Ruedemann (1912: pls 59, 62). The Grossopterus appendage is similar to that of $H$. socialis, at least in the proximal region. Grossopterus has only two segments which suggests that it is a type B (?male) appendage, while the spatulate distal region might represent the fusion of the two elements forming the distal furca in other eurypterids. Drawings not to scale. 
division. The type A genital appendage (Fig. 4A) consists of three sections (proximal joint and distal joint plus a pair of tapering projections called the furca) and the proximal joint is large and is noticeably longer than the surrounding plate, the genital operculum. Braddy \& Dunlop (1997) reviewed previous attempts to assign the different morphologies to either males or females, settling on the interpretation that the type A morphology was female since it is associated in Baltoeurypterus with a pair of sclerotised, sac-like, internal structures interpreted as sperm-storing spermathecae.

In contrast, in most eurypterids the type B genital appendage, which in this model is implicitly male, has only two sections (proximal joint and furca). Here, the proximal joint is narrower and shorter. In most taxa where this structure is known, the type B proximal joint is about as long as, or barely extends beyond, the genital operculum, while in some taxa, e.g. Baltoeurypterus, it only extends about half way-down the genital operculum (Fig. 4B). Thus, both the number of elements (two or three), together with the length of the proximal joint (longer than or shorter/equal to the operculum), appear to be useful criteria for determining the sex of a eurypterid (Fig. 4); see also Tollerton (1989: fig. 13). These criteria are, however, less applicable to the apparently more derived genitalia of taxa like Slimonia and the pterygotids (see e.g. Waterston 1960, 1964). Both groups appear to show varying degrees of fusion compared to the Baltoeurypterus model. The type B appendage in Slimonia has an unusually elongate proximal joint (Fig. $5 \mathrm{~B}$ ) while in pterygotids the entire structure forms an ovoid or triangular plate (Fig. 5E).

Grossopterus: The genital appendage of $G$. overathi was described by Størmer (1934: fig. 3) in some detail and based on its overall length he originally interpreted it as a type A. In this fossil the right side of the genital operculum, and the succeeding operculum, or Blattfuss, is better preserved than the left (Fig. 3). Indeed the differences in ornamentation between the two sides (lunules on the right and fine, angled lineations on the left) may reflect the fact that the right side preserves the ventral surface of the operculum while the left side may be preserving structures at a different level; for example the poorly known dorsal surface of the operculum.

Anteriorly, the genital operculum of $G$. overathi (Fig. 3) projects slightly, with the projection formed from a double hump. The proximal joint is arrow-shaped anteriorly and on the right side the barb of the arrow is seen to merge with a transverse suture running part of the way across the genital operculum in a gentle curve and dividing the lunule ornament below it from an ornament of fine lines above. This fine, linear ornament continues across the top of the proximal joint. The proximal joint then continues behind the arrow-shaped part as a squat, slightly tapering tube. Pairs of strong lines running along the length of the proximal joint ornament the structure in this region, the outer lines curve laterally towards the anterior end and merge with the transverse suture (Fig 3). This pattern of lines



Fig. 5. Further comparisons of genital appendages in selected eurypterid taxa. A. Slimonia acuminata - type A appendage. B. S. acuminata - type B appendage. Both after Waterston (1960, text-figs, 1a, 3a). C. Hughmilleria banksii - type B appendage (?), after KjellesvigWaering (1951, text-fig. $1 \mathrm{H})$. D. Erettopterus bilobus - type A appendage. E. E. bilobus type $B$ appendage. Both after Waterston (1964, text-fig. 1). Like Grossopterus, H. banksii also appears to have a fused furca. The genital appendages of Slimonia and the pterygotids are increasingly derived from the (?plesiomorphic) Baltoeurypterus condition. Drawings not to scale. 
creates the back of the arrowhead. The proximal joint ends shortly before the posterior margin of the genital operculum. Tucked close behind the posterior end of the proximal joint, the mesial region of the operculum is developed into a small, rounded lobe (Fig. 3). This feature is only preserved on the right side in $G$. overathi and is observed quite commonly in eurypterids, where it is characteristic for the genital operculum (see e.g. figures in Størmer 1955).

Grossopterus overathi has no obvious distal joint in the genital appendage, and instead of the double-branched furca (e.g. Figs 4A-B, D-E) it has a single, spatulate plate (Figs $3,4 \mathrm{C}$ ). The proximal region of this plate has a distinct median suture line while the posterior margins are developed into a series of tooth-like projections. This serrated margin was one of Størmer's (1934, 1955) diagnostic characters, and when examined in detail the serrations on the fossil are restricted to the posterior end and the right side of the genital appendage. Care must be taken to distinguish between genuine serrations and preparation artefacts around the genital appendage, but Størmer's observation is confirmed in this study. This spatulate element in $G$. overathi extends a little beyond the succeeding operculum.

Since there are only two elements in the $G$. overathi genital appendage and since the proximal element does not extend noticeably beyond the operculum we suggest that it is more consistent with the type B appendage (Fig. 4). In this model MB.A. $2 \mathrm{a}+\mathrm{b}$ (the holotype) is interpreted as a male. We suggest that instead of a furca $G$. overathi has fused this paired element together into a single plate, and that the median suture is a relict of its paired origin. In his illustrations of the British species Hughmilleria banksii (Salter, 1856), Kjellesvig-Waering (1951: textfigs $1 \mathrm{H}, \mathrm{K}$, pl. 2, figs 4-5) showed what appears to be another example of a type $B$ appendage with the furca fused together into a single structure (Fig. 5c). Furthermore, if the eurypterid genital appendage is homologous with the paired gonopods seen in Xiphosura - which also occur in a reduced or modified form in certain arachnids - then the unfused furca seen in most eurypterid taxa should probably be interpreted as the plesiomorphic condition of the clade. Fusion of the furca into a single plate would, in this model, be an apomorphic feature within eurypterids, while the presence of a serrate margin is an autapomorphy which defines the genus Grossopterus.

\section{Systematic palaeontology}

Order Eurypterida Burmeister, 1843

Family Hughmilleriidae Kjellesvig-Waering, 1951 Genus Grossopterus Størmer, 1934

Type-species: Grossopterus overathi (Gross, 1933) Additional species: Grossopterus (?) inexpectans (Ruedemann, 1921)

Remarks: Grossopterus (?) inexpectans is known only from the carapace which, as Størmer (1934) remarked, is similar to that in G. overathi. The $G$. (?) inexpectans type was originally referred to the genus Pterygotus Agassiz, 1844 but from published descriptions this isolated carapace lacks the massive lateral eyes which are characteristic for pterygotids. However, it shows few reliable diagnostic characters. We have been unable to examine the type, but suspect that due to its incompleteness Ruedemann's species may have to be regarded as a nomen dubium.

\section{Grossopterus overathi (Gross, 1933)}

Figs 1-3, 4C

1933 Eurypterus (?) overathi Gross: 72-74, fig. 16, pl. 7, fig. 1. 1934 Grossopterus overathi (Gross) - Størmer: 288-291, figs 1,3 .

1955 Grossopterus overathi (Gross) - Størmer: 30, fig. 21 (4). 1973 Grossopterus overathi (Gross) - Størmer: 121.

Holotype and only specimen: MB.A. $2 a+b$; almost complete specimen preserving dorsal and ventral surfaces.

Diagnosis: Medium-sized eurypterids with a subrectangular carapace with incurving lateral margins and anterolateral eyes; lateral eyes not touching the margin. Metastoma cardioid. Type $B$ genital appendage distinctive, divided into two parts. Distal part spatulate, partly divided by a median suture and uniquely with marginal serrations. Emended from Størmer (1934, 1955).

Type-locality: Steinbruch Heider [Heider quarry], near Overath, Nordrhein-Westfalen, Germany. Holotype collected by Walter Gross in autumn, 1931.

Type-horizon: Overather Fischschichten, Wahnbach-Schichten, Early Devonian (Middle to Upper Siegennian).

Description: Total preserved length $194 \mathrm{~mm}$. Carapace subrectangular, wider than long; length $45 \mathrm{~mm}$, maximum preserved width $55 \mathrm{~mm}$. Lateral margin of carapace with distinctly incurving margin, narrowest about two thirds along its length. Right lateral eye tubercle small, length 
$9 \mathrm{~mm}$, and reniform. Lateral eye located anterolaterally close to, but not touching, lateral margin of carapace. Median eyes or ocelli indistinct. Prosomal appendages partly preserved. Chelicerae missing, but postcheliceral limbs robust and spinose. Limb VI modified into a paddle. Paddle unit forms an elongate oval, length $22 \mathrm{~mm}$, width $10 \mathrm{~mm}$. Metastoma cardioid, length $16 \mathrm{~mm}$, width $13 \mathrm{~mm}$. Opisthosoma relatively broad, length $149 \mathrm{~mm}$, maximum width $70 \mathrm{~mm}$, without strong differentiation between pre- and postabdomen. Posterior end of opisthosoma and telson absent. See also Størmer (1934) for further details.

\section{Affinities}

Gross (1933) provisionally compared his new fossil to species of Eurypterus de Kay, 1825 and Hughmilleria, ruling out the latter genus on stratigraphical grounds since it was not known at that time from the Devonian. Størmer (1934) noted that the lateral position of the lateral eyes, i.e. close to the carapace margin, was more like Hughmilleria than Eurypterus. He further commented that the prosoma was reminiscent of some stylonurid eurypterids, although the Overath fossil can easily be excluded from this group since it has leg VI modified into a paddle (Figs 1-2). Størmer (1934) also noted similarities with Slimonia in terms of the carapace shape and genital appendage, differentiating Grossopterus from this genus by the detailed morphology of the latter structure (see diagnosis above). Slimonia also has a unique type of leg spinosity (see e.g. Tollerton 1989) whereas that of Grossopterus is more typical of eurypterids. Unfortunately the absence of the telson makes it impossible to resolve whether this structure in Grossopterus was lanceolate, like Hughmilleria and most other eurypterids, or broad, which is very characteristic for Slimonia and the pterygotids.

Phylogenetic position: A provisional phylogeny including $G$. overathi and representatives of potentially related genera (see above) within the Hughmilleriidae, Slimoniidae and Pterygotoidea was constructed to attempt to show the position of Grossopterus. The two previous unpublished analyses (Plotnick 1983, Braddy 1996) are unsatisfactory due to the relatively small number of characters used, compared to the large number of genera included, which resulted in trees lacking proper resolution. The model presented here builds on that of Plotnick \& Baumiller (1988) and is based on apomorphic characters identified as part of a larger, ongoing phylogenetic study of the entire Eurypterida by one of us (OET). This work in progress aims to resolve eurypterid relationships quantitatively through a comprehensive parsimony analysis and the tree shown in Figure 6 should be taken as a preliminary result of this project, albeit one for which we have good synapomorphies.

Results and discussion: According to our model (Fig. 6), derived in part from new information regarding the position of the ocelli and shape of the metastoma in Grossopterus emerging from this study, we can now infer the position of G. overathi with respect to Slimonia and the hughmilleriids; the later represented here by Nanahughmilleria Kjellesvig-Waering, 1961 and Parahughmilleria Kjellesvig-Waering, 1961. Grossopterus can provisionally be placed as sister group to (Slimonia + pterygotids), while, at least based on the taxa studied here, Hughmilleriidae may turn out to be a paraphyletic group. An

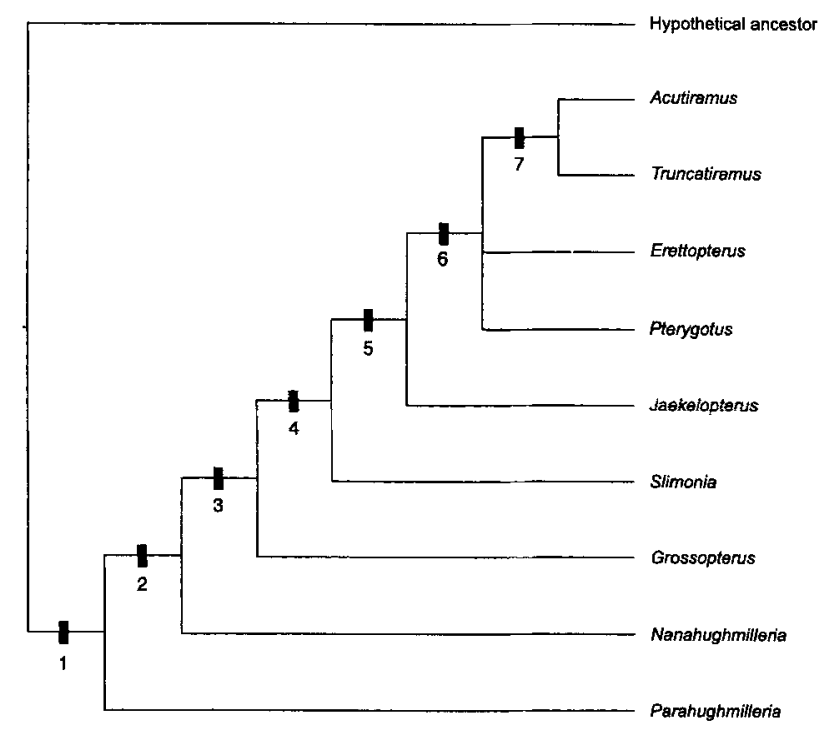

Fig. 6. Provisional cladogram of selected taxa used to infer the position of $G$. overathi and similar forms. The tree was constructed by hand based on characters identified as part of a larger (unpublished) analysis of eurypterid relationships (Tetlie in prep.). Suggested synapomorphies at the numbered nodes are: [1] Eyes antelateral to ocelli, ocelli central (cf. Tollerton 1989, fig. 7), eyes on anterior third; [2] Eyes on lateral third, lateral sclerites absent on operculum; [3] 1st order differentiation of opisthosoma absent; [4] Eyes oval and marginal, appendage II non-spiniferous, 2nd order differentiation of opisthosoma absent; [5] Eye length $>30 \%$ of prosomal length, chelicerae enlarged with teeth, pretelson with dorsal keel and postlaterally expanded; [6] Genital appendage type A undivided; [7] Largest principal tooth not perpendicular to chelae, 1st principal tooth on free ramus greater than that of the fixed ramus, keel of telson reduced. 
evolutionary scenario is suggested here in which relatively small-sized hughmilleriids with reniform, intramarginal eyes, spiniferous walking legs and a lanceolate telson evolved towards the Grossopterus condition with its slightly larger size and more anteriorly positioned eyes. This trend is continued in Slimonia, i.e. even larger size, marginal oval eyes, partial loss of spiniferous legs and development of a broader telson. The trend culminates in the pterygotids, reaching up to a gigantic two metres in length. Chlupác (1994) has estimated body lengths, excluding the chelicerae, of $230-250 \mathrm{~cm}$ in the Czech species Acutiramus bohemicus (Barrande, 1872). Other pterygotid characters are development of the chelicerae into massive, raptorial appendages, complete reduction of leg spination and huge, anteriorly placed eyes, with the eye length being about one third that of the prosoma.

Pterygotids: An interesting aspect of our model is that the pterygotids, which were partially unresolved in the analyses of Plotnick (1983) and Plotnick \& Baumiller (1988) show synapomorphies implying a slightly different topology to that expressed in these papers. In an unpublished study, Rawlinson (2000) investigated the functional morphology of the chelicerae of pterygotid eurypterids, identifying two main functional types: cutters and crushers based on their relative mechanical advantages (see Selden 1984 for details). Cutters were characterised by a mechanical advantage of less than 0.1, the presence of an enlarged principal tooth on the fixed ramus, and the inclined orientation of the proximal tooth on the free ramus. In a preliminary cladistic analysis based on data in Braddy (1996) together with new cheliceral characters, Rawlinson (2000) suggested a general evolutionary trend from crushers to cutters of the form: (Jaekelopterus (Pterygotus (Erettopterus (Acutiramus + Truncatiramus)))). Our results (Fig. 6) are derived from more characters, but resemble the tree of Rawlinson (2000) and suggest that the cutting type of chelicerae is synapomorphic for Acutiramus and Truncatiramus while the very broad telsons in Pterygotus and Acutiramus are convergent; something also suggested by Plotnick's (1983) study. However, we were unable at this stage to identify reliable synapomorphies which could resolve the relative position of Pterygotus and Erettopterus.

\section{Eurypterids and fish}

Romer (1933) suggested that various Silurian and Early Devonian jawless fish (e.g., Agnatha such as Heterostraci and Osteostraci) evolved dermal armour specifically as a defence against predation by eurypterids, and that the subsequent decline of eurypterids during the Devonian was due to the increasing dominance of faster-swimming, jawed fish. In support of this hypothesis, Romer (1933: 115) noted "Two apparently unassociated facts ...". First, the diversity and size of the eurypterids appears to have peaked around the late Silurian, coincidental with the acme in the agnathans. Plotnick \& Baumiller (1988: fig. 3) also demonstrated a sharp peak in pterygotid diversity at the end of the Silurian. Second, the decline in the eurypterids through the Devonian - they barely made it through to the Permian - coincides with a rapid increase in the numbers of jawed fish and a corresponding loss of these fishes heavy dermal armour. Of the eurypterid genera recognised by Tollerton (1989: tab. 8) about three-quarters (47 out of 62) occur within this late Silurian to Early Devonian time bracket, whereas only about a quarter of the genera (16 from 62) are recorded from the mid Devonian through to the Permian. Some genera fall within both time brackets, but given the questionable assignment of some material to taxa (cf. Tollerton 1994) it would be unwise to analyse these data in detail without taxonomic revisions concentrating on common genera reported as having long stratigraphic ranges.

Additionally, eurypterids are commonly fossilized in association with fish, especially in Silurian and Devonian sediments such as the Grossopterus type locality, the Wahnbach-Schichten fish bed at Overath discussed by Gross (1933); see also above. Romer (1933) listed several wellknown localities such as the Shawangunk Grits, USA, the Baltic and Bertie waterlimes, and the Old Red Sandstone of Scotland where eurypterids are found associated with fish, apparently to the exclusion of other potential predators on the vertebrate fauna. Recent descriptions of eurypterids from the Midland Valley of Scotland (Braddy 2000) and the Anderson River region of Canada (Braddy \& Dunlop 2000) again highlighted this frequent co-occurence of eurypterids and fish. Furthermore, in a detailed review of eurypterid palaeocommunities, Plotnick (1999) noted that in around one-third of the Silurian and Early Devonian eurypterid localities (where 
associations are known), eurypterids are associated with fish; see Plotnick (1999, appendix 10a, localities $1,17,23,28,41,45-47,49-54,57$, $59-61,63,64,66,68,70-72,79,80 \mathrm{~b}, 84$, and 91) for details. The question is whether these widely documented fossil associations are simply fortuitous or whether they imply strong ecological interactions such as predation?

Functional morphological studies of pterygotid chelicerae suggest that they were designed for the rapid capture of fast-moving prey (Selden 1984) and fish would be an obvious candidate. Selden also noted how the saw-like teeth on the chelicerae of the pterygotid Acutiramus resemble fish-descaling implements and thus might have been adapted specifically to deal with vertebrates. Rawlinson's (2000) conclusions on an evolutionary trend towards cutting pterygotid chelicerae have also been noted above. Although no direct evidence (in the form of gut contents or disjecta) for eurypterids preying on fish is known, putative eurypterid coprolites from the Hagshaw Hills of Scotland contain disarticulated fish fragments (Selden 1984), supporting Romer's general argument.

However, Romer's proposal is not without its critics. Recently, Gee (2000: 125$)$ stated that this hypothesis "... paints a cartoon version of reality ... playing down complex ecological interrelationships and ignoring other possibilities." Gee (2000) favoured an alternative interpretation in which the dermal armour of Agnatha primarily evolved as a phosphate store. Eurypterid-fish coevolution is an attractive hypothesis with some circumstantial evidence in its favour, but which is nevertheless difficult to prove quantitatively. In our analysis, Grossopterus resolves as the sister group of Slimonia plus the pterygotids and may therefore be part of a basal lineage in this ultimately successful clade which exploited the niche of large size and, perhaps, vertebrate predation.

\section{Acknowledgements}

We thank the Institut für Paläontologie of the MfN, Berlin for inviting this contribution, Dr. Christian Neumann (Berlin) for the loan of material in his care, Dr. Stefan Schultka (Berlin) for valuable advice on the Overath locality and Vera Heinrich (Berlin) for preparing the photographs. Drs Paul Selden (Manchester) and Carsten Brauckmann (ClausthalZellerfeld) are thanked for suggesting improvements to the manuscript. OET acknowledges NFR grant 145656/432 into eurypterid phylogeny and evolution.

\section{References}

Agassiz, L. 1844-1845. Monographie des poissons fossils du Vieux Grès Rouge ou Système Dévonian. 171 pp, folio, Jent \& Gassmann, Neuchâtel.

Barrande, J. 1872. Systéme silurien du centre de la Boheme. 1ére partic. Recherches paléontologiques. - Supplement au Vol. 1. Trilobites, crustacés divers et poissons. Prague.

Beall, B. S. \& Labandeira C. C. 1990 . Macroevolutionary patterns of the Chelicerata and Tracheata. In Culver, S. J. (ed.) Arthropod Paleobiology, Short Courses in Palaeobiology, No. 3: 257-284. The Paleontological Society.

Braddy, S. J. 1996. Palaeobiology of the Eurypterida. - Unpublished Ph.D. thesis, University of Manchester, $505 \mathrm{pp}$.

- 2000. Eurypterids from the Early Devonian of the Midland Valley of Scotland. - Scottish Journal of Geology 36: $115-122$.

Braddy, S. J. \& Dunlop, J. A. 1997. The functional morphology of mating in the Silurian eurypterid, Baltoeurypterus tetragonophthalmus (Fischer, 1839). - Zoological Journal of the Linnean Society 121: 435-461.

- 2000. Early Devonian eurypterids from the Northwest Territories of Arctic Canada. - Canadian Journal of Earth Sciences 37: 1167-1175.

Burmeister, H. 1843. Die Organisation der Trilobiten, aus ihren lebenden Verwandten entwickelt; nebst einer systematischen Uebersicht aller zeither beschribenen Arten. 148 pp., G. Reimer, Berlin.

Chlupáč, I. 1994. Pterygotid eurypterids (Arthropoda, Chelicerata) in the Silurian and Devonian of Bohemia. - Journal of the Czech Geological Society 39 (2-3): 147-162

Clarke, J. M. \& Ruedemann, R. 1912. The Eurypterida of New York. - Memoirs of the State Museum of New York 14: $1-439$.

de Kay, J. E. 1825. Observations of a fossil crustaceous animal of the order Branchiopoda. - Annals of the New York Lyceum of Natural History 1: $375-377$.

Dunlop J. A. \& Webster, M. 1999. Fossil evidence, terrestrialization and arachnid phylogeny. - The Journal of Arachnology 27: 86-93.

Gee, H. 2000. Deep Time: Cladistics, the revolution in evolution. 272 pp, Fourth Estate, London.

Gross, W. 1933. Die unterdevonischen Fische und Gigantostraken von Overath. - Abhandlungen der Preußischen Geologischen Landesanstalt (N. F.) 145: 41-77.

Kjellesvig-Waering, E. N. 1951. Downtownian (Silurian) Eurypterida from Perton, near Stoke Edith, Herefordshire. Geological Magazine 88: 1-24.

- 1961. The Silurian Eurypterida of the Welsh Borderland. - Journal of Paleontology 35: 789-835.

- 1964. A synopsis of the family Pterygotidae Clarke and Ruedemann, 1912 (Eurypterida). - Journal of Paleontology 38: $331-361$.

- 1973. A new Silurian Slimonia (Eurypterida) from Bolivia. - Journal of Paleontology 47: 549-550.

Page, D. 1856. Advanced text-book of Geology. 326 pp., William Blackwood \& Sons, Edinburgh.

Plotnick, R. E. 1983. Patterns in the evolution of the eurypterids. - Unpublished Ph.D. thesis, University of Chicago, 411 pp.

- 1999. Habitat of Llandoverian-Lochkovian eurypterids. In Boucot, A. \& J. Lawson (eds) Paleocommunities: A Case Study from the Silurian and Lower Devonian: 106-131. Cambridge University Press.

Plotnick, R. E. \& Baumiller, T. K. 1988. The pterygotid telson as a biological rudder. - Lethaia 21: 13-27.

Rawlinson, S. 2000. The functional morphology of raptorial appendages in predatory fossil arthropods. - Unpublished M.Sc. thesis, University of Bristol, 96 pp.

Romer, A. S. 1933. Eurypterid influence on vertebrate history. - Science 78: 114-117. 
Ruedemann, R. 1921. A new eurypterid from the Devonian of New York. - New York State Museum Bulletin 227-228: 88-92.

Salter, J. W. 1856. On some new Crustacea from the uppermost Silurian rocks. - Quarterly Journal of the Geological Society, London 12: 26-34.

- 1859. On some species of Eurypterus; with notes on the distribution of the species. - Quarterly Journal of the Geological Society of London 15: 229-236.

Sarle, C. J. 1903. A new eurypterid fauna from the base of the Salina in Western New York. - New York State Museum Bulletin 69: 1080-1108.

Schriel, W. 1933. Die Schichtfolge und die Lagerungsverhältnisse im Gebiet der unteren Agger und Sülz. - Abhandlungen der Preußischen Geologischen Landesanstalt (N. F.) 145: $3-40$.

Schweitzer, H.J. 1983. Die Unterdevonflora des Rheinlandes. 1. Teil. - Palaeontographica Abt. B 189: 1-161.

Selden, P. A. 1981. Functional morphology of the prosoma of Baltoeurypterus tetragonophthalmus (Fischer) (Chelicerata: Eurypterida). - Transactions of the Royal Society of Edinburgh: Earth Sciences 72: 9-48.

- 1984. Autecology of Silurian eurypterids. In Bassett, M. G. \& Lawson, J. D. (eds). Autecology of Silurian organisms. - Special Papers in Palaeontology 32: 39-54.
Størmer, L. 1934. Über den neuen von W. Gross beschriebenen Eurypteriden aus dem Unterdevon von Overath im Rheinland. - Jahrbuch der Preußischen Geologischen Landesanstalt 55: 284-291.

- 1955. Merostomata. In Moore, R. C. (ed.). Treatise on Invertebrate Paleontology, Part P, Arthropoda 2: 4-41. University of Kansas Press, Lawrence.

- 1973. Arthropods from the Lower Devonian (Lower Emsian) of Alken an der Mosel, Germany; Part 3, Eurypterida, Hughmilleriidae. - Senckenbergiana lethaea 54: 119-205.

Tollerton, V. P. Jr. 1989. Morphology, taxonomy, and classification of the order Eurypterida Burmeister, 1843. -- Journal of Paleontology 63: 642-657.

- 1994. The myth of Ordovician eurypterids in New York State. - Geological Society of America, Abstracts with Programs 26 (3): 76.

Waterston, C. D. 1960. The median abdominal appendage of the Silurian eurypterid Slimonia acuminata (Salter). - Palaeontology 3: 245-259.

- 1964. Observations on pterygotid eurypterids. - Transactions of the Royal Society of Edinburgh 66: 9-33.

Wills, L. J. 1965. A supplement to Gerhard Holm's ,Über die Organisation des Eurypterus fischeri Eichw.' With special reference to the organs of sight, respiration and reproduction. - Arkiv för Zoologie, Kungliga Svenska Vetenskaps Akademi, Serie 2, 18: 93-145. 